\title{
Research on Incubation of Characteristic Industry in Nationalities University
}

\author{
Li ZUO', a , Kai-Jie YOU ${ }^{2, b}$, Shuang LIU ${ }^{3, c,{ }^{*}}$ \\ ${ }^{1}$ Economics and Management School, Dalian Nationalities University, Dalian, China \\ ${ }^{2}$ Economics and Management School, Dalian Nationalities University, Dalian, China \\ ${ }^{3}$ School of Computer Science and Engineering, Dalian Nationalities University, Dalian, China \\ azuoli_anna@yahoo.com, ${ }^{b} 443494301 @ q q . c o m$, Is_liaoning@163.com \\ ${ }^{*}$ Corresponding author
}

Keywords: Incubation, Characteristic industry, Nationality University.

\begin{abstract}
Incubation of characteristic industry in Nationality University, the theme discussed in this paper, is to prove the feasibility of national characteristic industry's incubation in Nationality University and discussed different kinds of support to national characteristic industry's incubation in Nationality University. Nationality University plays an important role in the development of national characteristic industry's incubation.
\end{abstract}

\section{Introduction}

Since 1987 Chinese first business incubator was born, high new technology enterprises such as the Information Technology, the Photoelectron Industry and the Biomedical enterprises for office are the material supply of business incubators, which play an increasing important role in economic development. But there are not many resources in minority areas that occupied $64 \%$ land area in high technology industries, hence the incubation of national characteristic industry would be conducive to the economic development of minority areas. Incubation of national characteristic industry in Nationality University, the theme discussed in this paper, is to use the resources of talents and scientific research in Nationality universities to promote the development of incubation of national characteristic industry.

\section{Feasibility of National Characteristic Industry's Incubation}

\section{The inseparable relationship of Incubation and Universities}

From the birth of incubation, the Universities have had an inseparable relationship with it, not only providing theoretical basis and technical assistance, but also as the natural hotbed of incubation industry.

In the $1990 \mathrm{~s}$, there is an emerging power of incubation in Chinese University, many university science park had been built, such as Peking University Science Park, Tuspark. By 2010,China has had 86 university national science parks, 8.29 million square meters for incubation, 1235 research and development institutions, 1185 approved patent of inventions, transforming 2306 items of scientific and technological achievements above the provincial level and 6583 incubated enterprises.

These data illustrate that the importance of universities national science parks .Under the leadership of the government, using Comprehensive resource advantages of talents, technology, knowledge, experimental facilities and cultural atmosphere to provide services for the growth of incubated enterprises.

\section{The support of the government}

The development of incubator needs joint help of universities, scientific research institutions and government. Chinese government provides financial supports and preferential policies to incubator. 
Take Optics Valley of China for example, government offer financial investment, capital fund and discount government loans to it, the annual sum would not less than 3 billion RMB. And that local government would put into more than $40 \%$ annual financial revenue. Beyond those the science and technology department torch high technology industrial development center is the particularly department to manage incubation, which offer guiding policies and scientific development plans to incubation.

\section{The entering of private capital and venture capital}

With the incubator developing, the private capital and venture capital enters into the incubation of national characteristic industry in Nationality University irresistibly. Feasibility of incubation of national characteristic industry in nationality university faces the biggest problem is the lack of capital. Besides of the support of governmental capital, the entering of private capital and venture capital would bring market mechanism to the incubation of national characteristic industry in Nationality University to improve the profitability of incubation. Under the new model of coalitionbuilding between private enterprise and university, incubator in university would generate service fees from incubated enterprises or obtain long-term benefits by providing services as an investment to enterprises. Thus, incubation of national characteristic industry in Nationality University not only can be the non-profit incubator with the capital of government but also could become the separate entity in the market. The entering of private capital and venture capital enhance the feasibility of national characteristic industry's incubation in Nationality University.

\section{External Factor Evaluation of National Characteristic Industry in Nationality University}

Table 1. EFE of National Characteristic Industry Incubation in Nationality University

\begin{tabular}{|c|c|c|c|c|}
\hline \multicolumn{2}{|c|}{ Key factor } & Weight & $\begin{array}{c}\text { Grad } \\
\text { e }\end{array}$ & $\begin{array}{l}\text { Weighted } \\
\text { score }\end{array}$ \\
\hline \multicolumn{2}{|r|}{ External opportunity } & & & 2.85 \\
\hline 1. & The support of torch plan & 0.15 & 4 & 0.6 \\
\hline 2. & The support of governmental policy & 0.15 & 3 & 0.45 \\
\hline 3. & The support of governmental capital & 0.15 & 3 & 0.45 \\
\hline 4. & Resources of nationality university & 0.15 & 3 & 0.45 \\
\hline 5. & The entering of private capital and venture capital & 0.10 & 2 & 0.2 \\
\hline 6. & The need to develop national characteristic industry & 0.1 & 1 & 0.1 \\
\hline 7. & The objective requirement of West Development & 0.1 & 1 & 0.1 \\
\hline 8. & the need of diversity of incubation model & 0.1 & 1 & 0.1 \\
\hline \multicolumn{2}{|r|}{ External threats } & & & 2.2 \\
\hline 1. & The Backward economy of minority regions & 0.3 & 3 & 0.9 \\
\hline 2. & The lack of ethnic minority's talents & 0.3 & 2 & 0.6 \\
\hline 3. & Inconvenient transportation of minority regions & 0.2 & 2 & 0.4 \\
\hline & the backward science and technology of minority & 0.3 & 1 & 0.3 \\
\hline
\end{tabular}

Facing with a complicated external environment, national characteristic industry in minority has its opportunities and threats, as shown in TABLE 1. Besides of the support of government and 
Nationality University, the entering of private capital infuses a new vitality to national characteristic industry incubation. And meeting the objective need of West Development and diversity of incubation models, national characteristic industry incubation makes contributions to the development of national characteristic industry and economy of minority regions. On the other hand, incubation of national characteristic industry should over the lack of talents, technology and backward of economy and transportation.

The table 1 illustrates that the external opportunity of national characteristic industry's incubation in minority scored 2.85 and the weighted score of external threats is 1.8 , and the weighted average scores of EFE is 2.5, so that national characteristic industry's incubation in minority has a good external environment. Nationality University as the scientific-research bases of national characteristic industry combined scientific research, teaching with product to use innovations in the incubation of national characteristic industry and to transfer achievements in scientific research to real production.

\section{Support of Nationalities University to Characteristic Industry Incubation}

\section{Providing support of minority's talents}

Nationality universities as the base of developing minority's talents, provide technical persons and professional managers who learn about the actual evolution of minority regions and minority characteristic industry. Because that in nationality universities most students and teachers come from minority regions.

Nationality universities could offer courses about national characteristic industry incubation to professionals for incubation and encourage students to creating their own. Likewise, universities could make police for professors to set up incubate enterprises, providing the help of patent application and using public resources on free. Take East China Normal University for example, the university will sign an agreement with Professors or other scientific and technical personnel to ensure their benefits during they built enterprises.

\section{Support of professional knowledge}

Nationality universities have many patents, technology and available scientific data which are from fieldwork. Those provide a strong information network which can offer a scientific development planning for national characteristic industry incubation and provide consulting services for incubated enterprises in the professional field. Thus, transferring knowledge to productive, nationality universities provide the support of professional knowledge and variety of reference services for incubated enterprises to generate profits.

Meanwhile, nationality universities have strong research power that could provide innovative viewpoints for incubated enterprises. During the 10th Five-Year Plan, Chinese universities took 973 items of scientific project as the first undertaking entity which accounts for $54.5 \%$ of the total projects, and among these, 85 items as the chief scientists. [4] So that, with the help of minority, enterprises of national characteristic industry will be innovative and unique in the market competition.

\section{Support of information network}

Through computer technique, nationality universities could build a public information system that could promote enterprises acquire available information, achieve virtual technology and offer kinds of services.

On the other hand, through the public information system, managers of incubated enterprises could exchange experience and information with each other. Thus, enterprise easier to make a deal with other incubated enterprise then without the support of information network. In addition to this, exchanging experience and available information could bring the psychological and emotional support to entrepreneurs. 


\section{Support of incubation's training}

Nationality University as the educational institution should use the educational resources to train entrepreneurs and managers of incubation. Take Huazhong University of Science and Technology for instance, this university that combined with the Wuhan Huagong Tech Business Incubation has offered business training courses for potential entrepreneurs, entrepreneurs and managers of incubation. And participants of these training courses have been organized to investigate large-scale incubations in other province. So that participants could achieve successful experiences and advanced management modes from the investigation of other incubations.

\section{Conclusion}

With the support of government and universities, incubation of national characteristic industry in Nationality University has a promising prospect. Through the EFE we can see that also. The support of Nationality University plays an important role in the development of national characteristic industry's incubation. Nationality university not only provide a systematic development environment, but also offer the talents, professional knowledge and information network for incubation of national characteristic industry, which ensure the success of national characteristic industry's incubation and conductive to the economic competitive power of minority regions at last.

\section{Acknowledgement}

This research was Project 71303031 supported by the National Natural Science Foundation of China.

\section{References}

[1] The Analysis on the Relation between the University Science and Technology Park and the University ZHENG Xu, WANG Yuxi, WU Aiping ( Dalian Jiaotong University, Dalian 116028, China).

[2] Seizing Opportunities and Meeting Challenges to Develop Wuhan East Lake National Optoelectronic Information Industry Base, Construction leading group office of the Optics Valley of China, [J] Science \& Technology Progress and Policy, 2006(5).

[3] Incubation Mode of the University Science Park Based on the Triple Helix Model, ZHANG Tienan CHEN Juan ( Harbin Engineering University, School of Economy and Management, Harbin 150001).

[4] Research on the Formation mechanism of University Derivative Enterprise Based on the Triple Helix Mode--Shanghai Universities Derivative Enterprise, Zhang Yunyi, Zeng Gang (City and Regional Economy School, East China Normal University, Shanghai 200062).

[5] Discussing the University Technology Business Incubator's functions L I Xin (College of Management, Huazhong University of Science and Technology, Wuhan 430074, China).

[6] Lichtenstein Gregg. The Significance of Relationships in Entrepreneurship Development: A Case Study of the Ecology of Enterprise in Two Business Incubators [M] .Athens, $\mathrm{OH}$ : National Business Incubation Association, 1992.

[7] Developing the Science and education advantage of University and Enhancing the training of incubation, Li Juan, Wuhan Huagong Tech Business Incubation, [J] Science \& Technology Industry of China,2008(11). 